\title{
REVIEW
}

\section{ARTIFICIAL PENAEID LARVAL DIETS}

\author{
K. CHITRAVADIVELU* \\ Marine Science Laboratory, University College of North Wales, Bangor, United Kingdom.
}

(Date of receipt : : 08 February 1991)

(Date of acceptance : 21 April 1992)

\section{Introduction}

Shrimps are considered as a luxury food commodity in international trade. They are cursently cultured in over 40 countries throughout the world with approximately 31,000 farms, 3,500 hatcheries and 765,000 ha. of ponds. Shrimp production was 170,990 tons in 1984 and has been projected to reach 489,990 tons by 1990 and double this by the end of the century. ${ }^{1}$ High price incentives, generation of employment, foreign exchange earsings, development of culture technology and the availability of shrimp larvae from hatcheries have led to this remarkable expansion in the commercial culture of shrimps.

Shrimp hatcheries operate as a separate industry today and in most countries, their numbers are increasing rapidly to keep pace with the demand for post-larval juveniles. Successful shrimp larval production requires timely supply of essential food organisms in sufficient quantities. The non-feeding nauplii larvae on metamorphosis to the protozoea stage are herbivorous and feed on unicellular algae. As the larvae progress to the mysis stage they become omnivorous and require live zooplankton. The most popular choices are rotifers and Artemia nauplii for mysis and post larval stages. Most hatcheries usually maintain continuous algal cultures of species of Chaetoceros, Skeletonema, Tetraselmis and Chlorella to meet their nutritional requirements. Artemia nauplii are most conveniently hatched as required from commercially available dessiccated cysts. However, these food items are expensive, difficult to culture and maintain, often nutritionally variable and deficient in polyunsaturated fatty acids and may introduce pollutants and disease. ${ }^{2,3}$ Therefore, the need for a nutritionally balanced artificial diet for shrimp larvae to replace natural foods has been felt by the shrimp culturists. The search for an efficient delivery system, which could be used to supply the nutritionally balanced artificial diet to the shrimp larvae without loss of nutrients when suspended in sea water, avoiding problems of bacterial contamination, preventing fouling of larval cultures and clumping of nutrient particles, started in the early 1970s. The present paper attempts to review briefly the progress made so far. 


\section{Membranes of the microencapsulated diets}

Jones et al. ${ }^{2}$ successfully reared Artemia with simple diets encapsulated within a nylon cross-linked protein membrane. The interfacial polymerisation used in the preparation of the nylon-protein microcapsule was based on the method described by Chang et al.. ${ }^{4}$ The successful application of microencapsulated diets for feeding penaeid larvae was first demonstrated by Jones et al. ${ }^{5}$ rearing of Penaeus japonicus. The cross-linked nylon-protein microcapsule was suitable for laboratory scale investigations, the membrane wall was too thin to withstand drying, not digestible and therefore did not provide an ideal diet and thus found to be impracticable for use on a commercial scale. Jones et al. $^{5}$ replaced the nylon portion of the capsule by a biodegradable cross linked protein wall. These protein walled microcapsules can be dried for storage and rehydrated for use as a larval feed because the protein wall is semi-permeable. The protein walled microcapsule is prepared by the emulsification of the dietary components in aqueous solution in cyclohexane containing a natural surfactant. Then by interfacial polymerisation using an acid chloride, the active sites on protein molecules contained within the diet are cross-linked. The cross-linked protein microcapsules are freeze-dried after terminating the reaction. ${ }^{3}$ Freeze-dried, cross-linked, protein-walled microcapsules so developed came into commercial production as larval diets for shrimps by Frippak Feeds, England.

\section{Particle size and energy requirements}

Clark et al. ${ }^{6}$ using inert powdered carbon in laboratory feeding studies of $P$. monodon larvae determined the particle sizes ingested by the different larval stages and concluded that particle size is a major factor limiting the performance of encapsulated feeds for the early algal feeding larval stages. Amjad et al. ${ }^{7}$ reported the optimum particle sizes inigested by $P$. monodon larvae fed on carbon particles and latex beads.

Kumarly et al. ${ }^{7}$ estimated the daily and total developmental energy requirements and computed the assimilation, gross growth and net growth efficiencies for individual stages of $P$. monodon larvae. The nutritional requirements and feeding behaviour of the larvae were then investigated using the technique of microencapsulation as the method to deliver artificial diets. Kumaly et al. ${ }^{8}$ using algae, Artentia and microencapsulated diets determined the ingestion and respiration rates over a range of temperatures for $P$. monodon larval stages. Using these data together with growth and assimilation rates, the preliminary energetic requirements of $P$. monodon larvae have now been determined. The survival and growth rate attained on the artificial diets have been found to be comparable to those reared on live feeds. 


\section{Microencapsulated, microbound and spray dried diets}

Today, of a range of artificial larval shrimp diets available in the market as partial replacement for live feeds for the culture of penaeid larvae only Frippak feed is microencapsulated, others are either microbound particulates or spray dried (Table 1). Amjad et al. ${ }^{9}$ and Jones et al. ${ }^{10}$ have evaluated the performance of these artificial diets in respect to particle size, leach rate, gross nutritional ccatent and water quality factors such as $\mathrm{NH}_{3}, \mathrm{NH}_{4}$ and $\mathrm{NO}_{2}$, conducting controlled trials with $P$. monodon larvae from single spawning from protozoea I to port-larva $\bar{i}$ stages. Figure 1 shows the organic content and dietary composition of some larval feeds compared to live feeds. ${ }^{11}$ The percentage loss of soluble compounds from some artificial larval diets over 24 hours in sea water at $28^{\circ} \mathrm{C}$ is shown in Figure 2. Leach loss of Frippak feed is the least with $18 \%$, over a period of 24 hours.

Table 1: Artificial diets used in comparative larval rearing triais with $P$. monodon .

\begin{tabular}{|c|c|c|}
\hline Artificial diets & Feed type & Co-feed \\
\hline Feed $F$ (Frippak) & Microencapsulation & Microalgae $10 \mathrm{C}^{*} \mu 1^{-1}$ \\
\hline Feed $\mathrm{C}^{+}$ & $\begin{array}{l}\text { Spray dried } \\
\text { formulation }\end{array}$ & $"$ \\
\hline Feed $\mathrm{A}^{+}$ & Microparticulate & $"$ \\
\hline Feed $B^{+}$ & Microparticulate & $"$ \\
\hline Feed $\mathrm{G}^{+}$ & Microparticulate & $"$ \\
\hline Feed $\mathrm{D}^{+}$ & Spray dried (yeast) & $"$ \\
\hline Feed $\mathrm{E}^{+}$ & Spray dried (algae) & $"$ \\
\hline Feed L (control) & Live feed & $\begin{array}{l}\text { Microalgae } 40 \mathrm{C} \mu \mathrm{I}^{-1} \\
\text { and Artemia nauplii } \\
5 \mathrm{ml}^{-1}\end{array}$ \\
\hline
\end{tabular}

+Refers to popular penaeid larval diets available in the market.

- Cells per micro-litre

Amjad et $a l .{ }^{9}$ have demonstrated a strong correlation between growth and survival of larvae and stability (leach loss), rather than with nutritional content and particle size of feed. Encapsulated diets have achieved low leach loss, stable acceptable particle size and a high organic content and consequently high larval survival in laboratory trials when used as a total replacement for live feeds. 


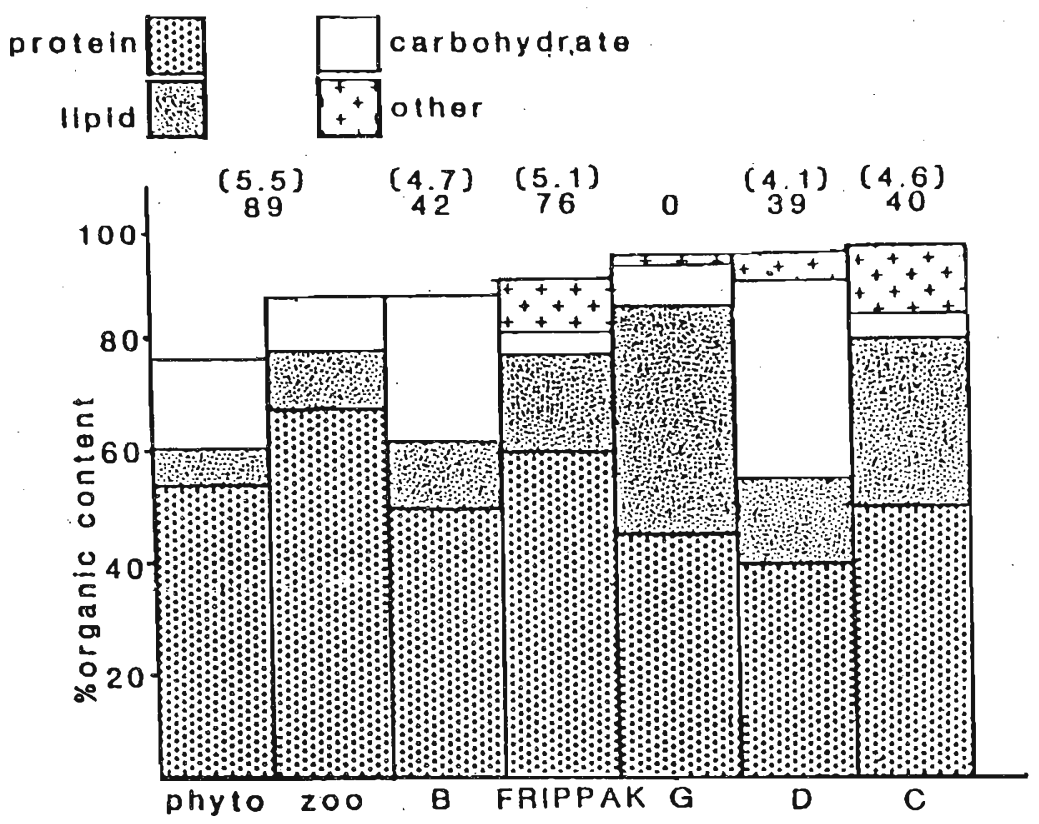

Figure 1: Organic content (ash free dry wt) of leading artificial larval feeds, together with protein, lipid, carbohydrate and corresponding larval growth (G) in $\mathrm{mm}$ and percentage survival (S) ${ }^{9}$ compared to live feeds ${ }^{11}$ (Raymont, 1983). (B-D are feeds referred to in Table 1.)

The Frippak feeds which are now available in the market have been considerably improved over the earlier products with the establishment of the correct capsule size range of $05-30 \mu$ for PZ1 - M3 stages and upto $250 \mu$ for the post-larval shrimps. The capsule is now a complete nutritional package with water soluble vitamins loaded in it with $49 \%$ protein, $27 \%$ carbohydrate, $13 \%$ lipid, vitamins, and $11 \%$ ash.

Jones et al. $^{3}$ have shown that less than $20 \%$ of dietary solubles are lost after 24 hours in water and that bacteria attach to the walls of the capsule rather than the blooms in the culture medium. They have suggested that these bacteria could be ingested together with the capsule, contributing toward micronutrients.

In shrimp hatcheries, many of the diseases prevalent are transmitted by the contaminated live feeds carried by the organisms themselves or by the culture medium. ${ }^{12}$ Microcapsule diets eliminate the contamination carried by organisms. It will soon be possible to supply prophylactics within the microcapsule ensuring that the drugs reach the target, thus reducing the amount of antibiotics currently added to the culture medium in hatcheries.

Recent trials with diets prepared with processed algae and algal extracts, have indicated a better growth and survival rate than live algal food itself in $P$. monodon 


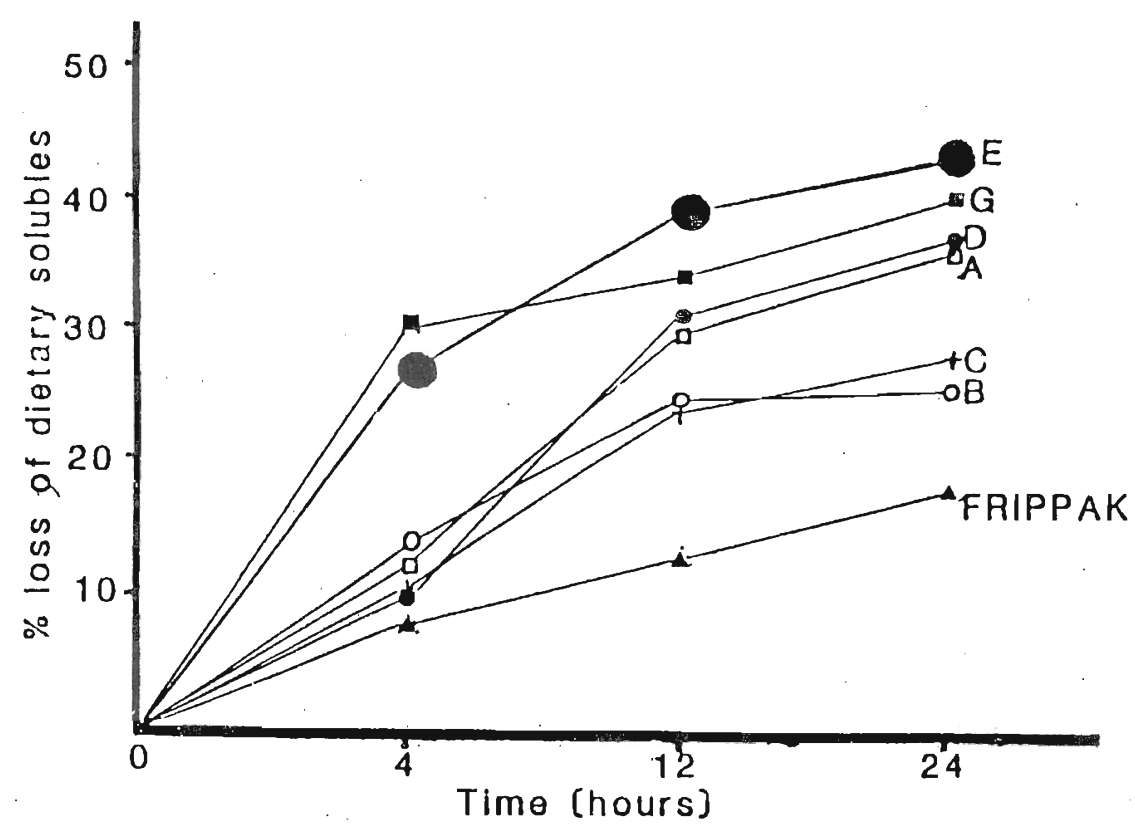

Figure 2: Percentage loss of soluble compounds from leading artificial larval diets over $24 \mathrm{~h}$ in seawater at $28^{\circ} \mathrm{C} .{ }^{9}$ (Feeds A-G refer to those given in Table 1 ).

larvae, indicating that some active factors in algae could be responsible for this enhanced growth.

Microencapsulated diets have now become a standard tool for the study of crustacean larval and post-larval nutritional requirements and the use of these diets have been extended to the nutritional studies of bivalves and fish larvae. ${ }^{13}$ The current target of research in penaeid larval nutrition of an efficient hundred percent artificial diet seems attainable in the near future. This would mean a more profitable shrimp culture that would expand to meet the increasing world demand for shrimps.

\section{Acknowledgements}

This review was prepared during a sabbatical at the Marine Science Laboratories of the University College of North Wales, U.K. I wish to thank Dr Jones for reading the manuscript and for his valuable suggestions. 


\section{References}

1. Rosenberry B. (1988). World shrimp farm. Aquaculture digest, U.S.A., pp. 1-24.

2. Jones D.A., Manford J.G., \& Gabbot P.A. (1974). Microcapsules as artificial food particles for aquatic filter feeders. Nature 247: 233-235.

3. Jones D.A., Holland D.L. \& Jabborie S. (1984). Penaeid shrimp hatchery trials using microencapulated diets. Aquaculture 64: 133-146.

4. Chang T.M.S., Macintosh F.C., \& Mason S.C. (1966). Semipermeable aqueous microcapsules. 1. Preparation and properties. Canadian Journal of Physiology and Pharmocology 44: 115-128.

5. Jones D.A., Kanazawa A. \& Rahman S.A. (1979). Studies on the presentation of artificial diets for rearing the larvae of $P$. japonicus Bate. Aquaculture 17: 33-43.

6. Clark J., Jones D.A. \& Kurmaly K., (1986). Penaeid larval rearing on microencapsulated feeds. In: First Inter-American Congress of Aquaculture (Eds. C.M. Volker and A. Volker). 14-21 Sept. 1986. Salvodor, Brazil.

7. Kurmaly K., Jones D.A., Joule A. \& East J. (1989). Comparative analysis of the growth and survival of Penaeus monodon larvae from protozoea 1 to Post-larva 1 , on live feeds, artificial diets and on combination of both Aquaculture 81: 27-45.

8. Kumarly K., Yule A. \& Jones D.A., (1989). An energy budget for the larval development of $P$. monodon. Aquaculture 81: 13-25.

9. Amjad S., Chitravadivelu K. \& Jones D.A., (1989). Advances in penaeid larval feed technology. Paper presented at the Forum on New technologies in Aquaculture. Malaysian Fisheries Society and the Ministry of Science, Technology and Environment. University Pertanian Malaysia, 17 Aug. 1989.

10. Jones D.A., Amjad S. \& Chitravadivelu K., (1989). Comparison of artificial feeds used in penaeid shrimp hatcheries. Proceedings of the Third Egyptian - British Conference on Animal, Fish and Poultry Production. Alexandria, pp. 7-22.

11. Raymont J.E.G., (1983). Plankton and productivity in the oceans. Pergamon Press, Oxford. pp. 660.

12. Spotte S.H. (1971). For general rules for use of live foods. S.E.A. Scope, 2(1).

13. Jones D.A., Holland D.L. \& Jabborie S.,- (1984). Current status of microencapsulated diets for aquaculture: In: Proceedings of the 5th International Symposium on Microencapsulation (Ed. T.M.S. Chang). Applied Biochemistry Biotechnology 10: 275-288. 